\title{
Validity of Mathematics Learning Devices Based on M-APOS Theory to Improve The Problem Solving Ability of Students Class VII Junior High School
}

\author{
$1^{\text {st }}$ Layla Fadhilah \\ Magister of Mathematics \\ Padang State University \\ Padang, Indonesia \\ fadhilah.layla@Yahoo.com
}

\author{
$2^{\text {nd }}$ Yerizon \\ Magister of Mathematics \\ Padang State University \\ Padang, Indonesia \\ yerizon@yahoo.com
}

\author{
$3^{\text {th }}$ Armiati \\ Magister of Mathematics \\ Padang State University \\ Padang, Indonesia \\ Armiati_math_unp@yahoo.co.id
}

\begin{abstract}
This study aims to produce a valid mathematics learning devices for class VII junior high school. The developed devices are learning plan and student's worksheets based on M-APOS approach. The development model used in this research is a Plomp model consisting of 3 phases, that is preliminary research, prototyping stage, and assessment stage. But the focus of this research is prototype development stage that is in stage of validity by expert. Aspects assessed at the validation stage are aspects of language, aspects of presentation/didactic, content aspects, and aspects of graffiti. The final result of this research is to produce a valid mathematics learning device based on M-APOS.
\end{abstract}

Keywords-Validation, Learning Devices, M-APOS Theory

\section{INTRODUCTION}

Mathematics is a subject that has important roles and functions for students in every level of education ranging from elementary school (SD) even up to university for some majors. There are many reasons why mathematics has an important role or function for students. As stated by Cornelius that there are five reasons for the need to learn mathematics because mathematics is (1) a clear and logical means of thinking, (2) the means to solve problems of everyday life, (3) Patterns of relationship and generalization of experience, (4) means to develop creativity, and (5) means to raise awareness of cultural development [1].

Furthermore, Cockroft argues that mathematics needs to be taught to students because (1) Mathematics is regarded by most people as being essential, (2) Mathematics is only one of many subjects which are included in the school curriculum, (3) Mathematics provides a means of communication which is powerful, concise and unambiguous, (4) Mathematics can be used to present information in many ways, (5) Develop powers of logical thinking, accuracy, and spatial awareness, and (6) Give satisfaction to attempt to solve challenging problems [2].

From some of the opinion above, we can know that one of the learning mathematics function is as a tool to train the problem solving skills of learners. To perform the mathematical functions as a tools to train the problem solving skills of learners, then the ability to solve mathematical problems must also be one of the goals of learning mathematics itself. As stated in Permendikbud RI No.58 year 2014 at point 2 is one of the objectives of learning mathematics is that learners can use the pattern as a conjecture in problem solving and able to make generalizations based on phenomena or existing data. This means that the ability to solve mathematical problems is a goal of mathematical learning according to Permendikbud (government regulations).

Although problem-solving skills are very important in mathematics learning activities, the reality of student's problem-solving ability is still low. The low ability of mathematical problem solving of these learners can be seen from the results of literacy conducted by Fauzan and Tasman at junior/MTs level in West Sumatra. From the literacy results, it is found that $40.957 \%$ of students have low problem solving abilities, $34.574 \%$ have medium problem solving skills, and $24.468 \%$ have high problem solving abilities.It's mean that the ability to solve mathematical problems of learners at junior/MTs level in West Sumatra Tend to Low [3].

The low ability of problem solving mathematical learners canalso seen from the results of observations that have been done in several junior high school / MTs in Kab. Pasaman Barat. Observation is done by giving a problem-solving test. The test was given to the students of SMP N 2 Pasaman in class VII-5 followed by 22 students and in MTsS Darussalam in class VII-Pi followed by 31 students. Table 1 below shows the results of mathematical problem solving test of learners in SMP N 2 Pasaman and MTsS Darussalam Pinagar.

TABLE 1. OBSERVATION RESULTS OF MATHEMATICAL PROBLEM SOLVING TEST

\begin{tabular}{|l|c|c|c|c|c|}
\hline \multirow{2}{*}{ School } & \multicolumn{5}{|c|}{ Qualification Values (Percentage) } \\
\cline { 2 - 6 } & $\begin{array}{c}\text { Excel } \\
\text { lent }\end{array}$ & Good & $\begin{array}{c}\text { Satisfac } \\
\text { tory }\end{array}$ & $\begin{array}{c}\text { Less than } \\
\text { Satisfactory }\end{array}$ & $\begin{array}{c}\text { More Less } \\
\text { than } \\
\text { Satisfactory }\end{array}$ \\
\hline $\begin{array}{l}\text { SMP N 2 } \\
\text { Pasaman }\end{array}$ & $\begin{array}{c}13,6 \\
3\end{array}$ & 9,09 & - & 13,63 & 63,64 \\
\hline $\begin{array}{l}\text { MTs S } \\
\text { Darussala } \\
\text { m }\end{array}$ & $\begin{array}{c}16,1 \\
3\end{array}$ & 9,67 & 6,45 & 9,67 & 58,064 \\
\hline
\end{tabular}


From Table 1 we are able to know that the early ability to solve mathematical problems of students both in SMP N 2 Pasaman and MTs S Darussalam is still relatively low.

From the observations that have been done by the researchers, the low ability of problem solving learners caused by several factors, including: (1) the lack of learning resources used in the learning process, (2) Student's Worksheets used so far does not contain adequate activities for learners to construct his understanding to find a mathematical concept, (3) the problems that exist in Student's Worksheets used so far do not contain the contextual or story problem so that learners are not accustomed to solving the story problem, while for the present era learners are expected to be able to do the HOTS one of the criteria of the problem is contextual, and (4) the activities in the Learning plan do not show the activities that lead the learners to be active and to be able find the mathematical concepts learned

From the problem above, it can be concluded that Learning planand Student's Worksheets used so far is not optimal. Where learning plan and student's worksheets used so far has not been supporting the learning activities of learners to be able to improve problem-solving skills. It is very unfortunate that the learning plan and student's worksheets used in schools so far has not been fully able to meet the needs of learners. Learning plan is a tool that can assist teachers in managing the stages to be done in the classroom and student's worksheets can facilitate teachers and learners in implementing learning in the classroom. Student's worksheets can improve the problem solving ability of learners, because in student's worksheets loaded questions that will guide learners to train problem-solving skills. So, learning plan and student's worksheets are two things that help teachers and learners in learning.

Along with the need for learning plan and student's worksheets that can support the problem solving ability of learners, it is also necessary to have approach that can be used as a foundation in developing learning plan and student's worksheets. Learning plan and the developed student's worksheets will be more optimal in improving the problem solving ability of learners, if learning plan and student's worksheets is based on one learning approach that also has a goal to improve the problem solving ability of learners and teaches students how to solve a problem. One of the learning approaches used to achieve that goal is through the M-APOS theory approach.

The M-APOS theory is a modification of the theory of APOS (action, process, object, and schema). As stated by Lestari that the theory of M-APOS is a modification of the theory of APOS (action-process-object-scheme). Modifications are made to the activity phase, where the activities in the computer labs on the APOS model are replaced by the assignment of the recitation assignment given before the learning is carried out. Recitation tasks are presented in the form of a learner's activity sheet that guides and assists learners in studying concepts or solving mathematical problems [4]. M-APOS theory is a theory that is considered capable of improving the problem solving skills of learners, because in solving a problem will certainly involve a high-level thinking process. In this process of thinking, an idea cannot suddenly come to mind. Ideas occur after various symbols are processed so that it can be said that in the process of thinking it will pass through several mental reconstruction stages as follows: (1) action, at this stage the transformation of objects perceived by the individual as necessary, and instructions step by step (2) the process, which is a mental construct that occurs internally when a person has been able to perform the level of action repeatedly, (3) object, can be interpreted as something that resulted from mental done at the stage of the process, and (4) schema, which is a collection of actions, processes, and objects summarized into a scheme. The learning that has the characteristics above is the M-APOS learning model.

Based on the problems that have been described above, the researcher develops an M-APOS basis learning device. The development model used in this research is the Plomp model which has three stages, namely the introduction stage, the development stage or the prototype making, and the assessment stage [5]. The purpose of this development is to acquire learning tools that are valid, practical, and effective. This means that learning devices that will be used in schools must be valid, practical, and effective first. But in this study focused on the validity of developed learning devices. So the research question in this research is "How is validity of mathematics learning devices based on M-APOS theory to improve the problem solving ability of students class VII junior high school?

\section{THE RESEARCH METHOD}

This research is a research development with development of Plomp model. The author uses this model because it is more systematic, directed, analytical, and suitable for developing learning tools. The Plomp model consists of three phases, namely the preliminary research phase, the prototype development or prototyping phase, and the assessment phase (5). The validation stage is at the stage of development or manufacture of prototypes. Validation is done by 5 experts consisting of 3 mathematics experts, 1 Indonesian language expert, and 1 person from education technology experts. Mathematicians will review the device from content and didactic aspects, language experts will review from the language aspect, and educational technology experts will review from the aspect of graffiti. The instruments used to collect data are the learning plan and student's worksheets validation sheets that have been validated by 2 mathematicians and 1 language expert. In this study, the average score ( $r$ ) of expert assessment results is adjusted according to the criteria of device assessment based on the criteria of device validity according to Muliyardi which can be seen in Table 2 [6] 
TABLE 2. CRITERIA OF LEARNING DEVICED VALIDITY

\begin{tabular}{|l|c|}
\hline \multicolumn{1}{|c|}{ Interpretation } & Criteria \\
\hline $\mathrm{R} \leq 0,08$ & Invalid \\
\hline $0,08<\mathrm{R} \leq 1,60$ & Less valid \\
\hline $1,60<\mathrm{R} \leq 2,40$ & Quite valid \\
\hline $2,40<\mathrm{R} \leq 3,20$ & Valid \\
\hline $\mathrm{R}>3,20$ & Very valid \\
\hline
\end{tabular}

The device is valid if it has a average experts / validator score $>2.40$.

\section{RESULT AND DISCUSSION}

learning devices that developed in the research are learning plan and student's worksheets. Learning device development process refers to the plomp model. Next will be explained and discussed briefly the results of learning plan and student's worksheets validation based on M-APOS.

\section{Learning Plan}

The learning implementation plan developed in this research is based on the $\mathrm{m}$-apos approach, in which the core activities of better learning are on the steps of the m-apos approach (action, process, object, and scheme). Learning plan designed for math materials class VII SMP/MTs semester 2. In the validation phase, learning learning plan implemented by 4 experts consisting of 3 mathematicians and 1 person from the indonesian language. Aspects of learning plan are validated by the expert is linguistic, didactic / presentation, and content aspects. The validation result of m-apos-based learning plan by 4 people can be seen based on table 3 below.

TABLE 3. RESULTS OF THE VALIDATION OF THE IMPLEMENTATION PLAN OF LEARNING BY EXPERTS

\begin{tabular}{|c|c|c|c|c|c|c|}
\hline \multirow{2}{*}{$\begin{array}{c}\text { Rated } \\
\text { Aspect }\end{array}$} & \multicolumn{4}{|c|}{ Average score from validator } & \multirow{2}{*}{$\begin{array}{l}\text { Avera } \\
\text { ge }\end{array}$} & \multirow{2}{*}{ Kriteria } \\
\hline & $V 1$ & $V 2$ & V3 & V4 & & \\
\hline Linguistic & 3 & 4 & 3 & 4 & 3,5 & $\begin{array}{l}\text { Very } \\
\text { Valid }\end{array}$ \\
\hline Didactic & 3,25 & 4,00 & 3,50 & 3,88 & 3,66 & $\begin{array}{l}\text { Very } \\
\text { Valid }\end{array}$ \\
\hline Content & 3,03 & 4,00 & 3,34 & 3,94 & 3,58 & $\begin{array}{l}\text { Very } \\
\text { Valid }\end{array}$ \\
\hline Average & 3,09 & 4,00 & 3,37 & 3,93 & 3,60 & $\begin{array}{l}\text { Very } \\
\text { Valid }\end{array}$ \\
\hline
\end{tabular}

From Table 3 we can see that the learning implementation plan (learning plan) that has been designed by the researcher is valid for every aspect of the assessment (language, dictication, and content). This is because the compilation of learning plan in accordance with the provision of learning plan according to permendikbud number 81a year 2013. In addition, the learning plan that is compiled is valid because the aspects of presentation, language, and content have been in accordance or meet the criteria of good [7]. However, linguistic aspects get the lowest average compared to other aspects, this is because there are still many mistakes in typing and punctuation, then this needs to be corrected by the author.

In terms of the average rating each aspect is on very valid criteria. Nevertheless, there are still some things that need to be improved from the learning plan that has been designed by researchers. The following Table 4 shows sereval things that need to be revised on the learning plan based on the suggestion of the validator.

\section{TABLE 4. REVISED VALIDATION RESULTS} OF LEARNING PLAN

\begin{tabular}{|c|c|}
\hline Before revision & After revision \\
\hline $\begin{array}{l}\text { Lesson objectives are incomplete, } \\
\text { learning objectives adjust to abcd } \\
\text { (audience, behavior, conditioning, } \\
\text { degree). }\end{array}$ & $\begin{array}{l}\text { Complete learning objectives } \\
\text { and tailored to abcd (audience, } \\
\text { behavior, conditioning, degree). }\end{array}$ \\
\hline $\begin{array}{l}\text { Learning resources are less clear } \\
\text { (word "etc" remove, mention all } \\
\text { learning resources in detail) }\end{array}$ & $\begin{array}{l}\text { All learning resources are written } \\
\text { clearly }\end{array}$ \\
\hline $\begin{array}{l}\text { Motivation on preliminary activities } \\
\text { is not real }\end{array}$ & $\begin{array}{l}\text { Motivation on preliminary } \\
\text { activities is changed into } \\
\text { something real or real for } \\
\text { learners, for example with things } \\
\text { that are close to the learner }\end{array}$ \\
\hline $\begin{array}{l}\text { At the introduction stage there is no } \\
\text { teacher explanation of the lesson } \\
\text { steps to be taken }\end{array}$ & $\begin{array}{l}\text { Add a teacher's explanation of } \\
\text { the steps of the learning activities } \\
\text { at the introduction stage }\end{array}$ \\
\hline $\begin{array}{l}\text { Do not write down what student's } \\
\text { worksheets statement is used }\end{array}$ & $\begin{array}{l}\text { write down information for each } \\
\text { student's worksheets used for } \\
\text { each meeting }\end{array}$ \\
\hline $\begin{array}{l}\text { Attitudes observed in learning } \\
\text { activities are too numerous }\end{array}$ & $\begin{array}{l}\text { Minimize attitudes to be assessed } \\
\text { in the learning process, attitudes } \\
\text { assessed only that deemed } \\
\text { necessary and can be assessed } \\
\text { during learning alone }\end{array}$ \\
\hline $\begin{array}{l}\text { Not to mention the number of } \\
\text { questions that the learner will do as } \\
\text { an exercise in closing activities }\end{array}$ & $\begin{array}{l}\text { Mention the number of questions } \\
\text { a learner should do as an exercise } \\
\text { in closing activities }\end{array}$ \\
\hline $\begin{array}{l}\text { Not all the problems presented in } \\
\text { student's worksheets are written in } \\
\text { the learning plan }\end{array}$ & $\begin{array}{l}\text { Any problems given in the } \\
\text { learning activities should be } \\
\text { written in the learning plan }\end{array}$ \\
\hline
\end{tabular}

Based on some validator's suggestions above, researchers revise the developed learning plan, so that learning plan can be used to assist in the process of learning activities of mathematics.

\section{Student's Worksheets}

Student's worksheets is designed based on the results of preliminary analysis conducted by researchers to: (1) analysis of learners, (2) analysis of learning problems, and (3) concept analysis. From the preliminary analysis result, it is designed student's worksheets based on M-APOS on the material ofclass VII SMP/MTs semester 2. Students worksheets which has been designed validated by 5 experts consisting of 3 mathematicians, 1 language expert and 1 expert education technology. The didactic and content aspects were validated by 3 mathematicians, the language aspect validated by language experts and the aspect of graffitiality validated by educational technology experts. The average of student's worksheets validation results by experts can be seen in Table 5 below. 
TABLE 5. RESULTS OF VALIDATION OF STUDENT'S WORKSHEET BY EXPERTS

\begin{tabular}{|c|c|c|c|c|c|c|c|}
\hline \multirow{2}{*}{$\begin{array}{l}\text { Rated } \\
\text { aspect }\end{array}$} & \multicolumn{5}{|c|}{ Average Score from Validator } & \multirow{2}{*}{$\begin{array}{l}\text { Aver } \\
\text { age }\end{array}$} & \multirow[t]{2}{*}{ Kriteria } \\
\hline & $V 1$ & $V 2$ & $V 3$ & V4 & $V 5$ & & \\
\hline $\begin{array}{l}\text { Lingui } \\
\text { stic }\end{array}$ & - & - & - & 3,71 & - & 3,71 & Very Valid \\
\hline $\begin{array}{l}\text { Didact } \\
\text { ic }\end{array}$ & 3,14 & 4,00 & $\begin{array}{l}3,5 \\
7\end{array}$ & - & - & 3,57 & Very Valid \\
\hline $\begin{array}{l}\text { Conte } \\
\mathrm{nt}\end{array}$ & 3,20 & 4,00 & $\begin{array}{l}3,6 \\
7 \\
\end{array}$ & - & - & 3,63 & Very Valid \\
\hline $\begin{array}{l}\text { Graffi } \\
\text { ti }\end{array}$ & - & - & - & - & 3,86 & 3,86 & Very Valid \\
\hline \multicolumn{6}{|c|}{ Rata-rata keseluruhan } & 3,69 & Very Valid \\
\hline
\end{tabular}

From Table 5 we can see that all aspects assessed in student's worksheets are at very valid criteria. This means that student's worksheets has been developed feasible and can be used as one of the learning devices in the process of teaching and learning activities. The developed student's worksheets eligible for use because in the design process student's worksheets refers to the steps of making student's worksheets according to mone [8] and on matters contained in student's worksheets refer to prajitno's opinion [9].

Based on the average scoring score, all aspects of the assessment are at a very valid category. Nevertheless, there are still some things in the student's worksheets that researchers need to improve in order to make the student's worksheets better. The suggestion of student's worksheets improvement from the validators can be seen in Table 6 below

\section{TABLE 6. REVISED VALIDATION RESULTS OF STUDENT} WORKSHEET

\begin{tabular}{|l|l|}
\hline \multicolumn{1}{|c|}{ Before Revision } & \multicolumn{1}{|c|}{ After Revision } \\
\hline $\begin{array}{l}\text { Cover is less attractive and the } \\
\text { image on the cover is too small }\end{array}$ & $\begin{array}{l}\text { Fix the cover of student's } \\
\text { worksheets and display the } \\
\text { images that represent the contents } \\
\text { of student's worksheets }\end{array}$ \\
\hline $\begin{array}{l}\text { The title student's worksheets do } \\
\text { not use the word "activity 1, } \\
\text { activity 2, etc." }\end{array}$ & $\begin{array}{l}\text { Replacing "activity 1, activity 2, } \\
\text { etc." to student's worksheets 1, } \\
\text { student's worksheets 2, etc. " }\end{array}$ \\
\hline $\begin{array}{l}\text { Every problem on student's } \\
\text { worksheets has no number }\end{array}$ & $\begin{array}{l}\text { Numbering for each problem on } \\
\text { lkdp makes it easier to direct } \\
\text { learners in learning }\end{array}$ \\
\hline $\begin{array}{l}\text { There are still some sentences in } \\
\text { the student's worksheets that are } \\
\text { not yet complete }\end{array}$ & $\begin{array}{l}\text { Complete the sentence on student's } \\
\text { worksheets so as not to create } \\
\text { double meaning and learners more } \\
\text { easily understand the problem on } \\
\text { student's worksheets }\end{array}$ \\
\hline
\end{tabular}

Based on some of the validator's suggestionsabove, student's worksheets that has revised usedin learning process.

\section{CONCLUSION AND SUGGESTION}

Based on the results and discussion of the research found that learning tools developed by researchers have been valid and can be used in learning mathematics SMP/MTs class VII semester 2. The suggestions for the next researchers who develop learning tools to pay more attention to the accuracy of typing, sentences effective and in accordance with cognitive level of learners, and refer to the development procedures of clear learning plan and student's worksheets.

\section{REFERENCES}

[1] Abdurrahman, M, Anak Berkesulitan Belajar: Teori, Diagnosis, dan Remediasinya. Jakarta: Rineka Cipta, 2012.

[2] Cockroft, W. H, Mathematics Count. London: Commercial Colour Press, 1982.

[3] Fauzan, Ahmad dan Tasman, F Laporan Penelitian: Analisis Literasi Matematis Siswa SMP di Sumbar. Padang: Pascasarjana UNP, 2012.

[4] Lestari, Karunia Eka, "PenerapanModel PembelajaranM-APOS Untuk MeningkatkanKemampuanPemecahanMasalah Matematis Siswa SMP," Jurnal Pendidikan Unsika, vol. 3 No. 1. ISSN: 2338-2996, 2015.

[5] Plomp, T Dan N. Nieveen, Educational Design Research. Enshede: Netherlands Institute For Curriculum Development (SLO), 2013.

[6] Muliyardi, Strategi Pembelajaran Matematika. Padang: FMIPA UNP, 2002 .

[7] A. Majid, Implementasi Kurikulum 2013. Bandung: Interes Media, 2014

[8] Depdiknas, Panduan Pengembangan Bahan Ajar. Jakarta: Direktorat Jendral Manajemen Pendidikan Dasar Dan Menengah, 2008.

[9] Megawati, "Pengembangan Perangkat Pembelajaran Matematika Berbasis Pendidikan Karakter Dengan Pendekatan Contextual Teaching And Learning Untuk Siswa Kelas X Sekolah Menengah Atas," Tesis Tidak Diterbitkan. Padang: Program Pascasarjana UNP, 2014. 